\title{
DIVORCE AGREEMENTS: INDEPENDENT CONTRACT OR INCORPORATION IN DECREE
}

The extent to which agreements between spouses are effective means of settling the alimony and property rights involved in divorce actions is in many respects uncertain. ${ }^{1}$ The pitfalls besetting the draftsmen of such agreements, while less numerous than formerly, remain significant. At times, divorce agreement law seems slanted to protect wives in spite of themselves. Society's ambivalence toward divorce is often mirrored in the application of vague equity doctrines thwarting the spouses' freedom of contract. Income ${ }^{2}$ and gift tax ${ }^{3}$ legislation have brought added complications. The courts, while professing to favor these contracts, on occasion regard them with extreme suspicion. By ignoring the conflicting judicial decisions, writers have created an illusion of greater certainty than actually exists. ${ }^{4} \mathrm{~A}$ flood of conflicting case law has been the result.

Uncertainty in the handling of divorce agreements is due in considerable measure to the indiscriminate lumping together of divorce and separation agreements. ${ }^{5}$ While for many purposes, such treatment may be justified, at times the two kinds of agreements differ markedly. ${ }^{6}$ The distinction between them is made necessary by the radical change in the parties' relationship brought about by a divorce. The duty of support, which continues throughout marriage, whether or not the parties are living together, is abrogated completely by a divorce. This fact has significant legal consequences. For example, the doctrine that a wife cannot bargain away her right to be supported, ${ }^{7}$ and the rule that a lump sum payment is no defense to the wife's subsequent action for maintenance if the

${ }^{1}$ See generally, Lindey, Separation Agreements (1937); California Divorce Agreements: Alimony or Property Settlement?, 2 Stanford L. Rev. 731 (1950); Control of Post-Divorce Level of Support by Prior Agreement, 63 Harv. L. Rev. 337 (1949); Paradoxical Separation Agreement, 21 Rocky Mt. L. Rev. 434 (1949); Separation Agreement as a Bar to Alimony, 64 U.S. L. Rev. 62 (1930).

2 Int. Rev. Code § 22(b)(3), 26 U.S.C.A. \$22(b)(3) (1949).

3 Int. Rev. Code $\$ 1002,26$ U.S.C.A. $\$ 1002$ (1949).

4 See authorities cited note 1 supra.

5 For example, a presumption of fraud arises in both cases if the agreement's provisions are heavily weighted in favor of the husband. Compare Ballard v. Ballard, $177 \mathrm{Ky} .253,197$ S.W. 661 (1917), with Weeks v. Weeks, 143 Fla. 686, 197 So. 393 (1940).

${ }^{6}$ This is especially true in the area of remedies available to the wife in the event of her husband's failure to perform. While the marriage relation subsists, the husband's support duties may be enforced in a variety of ways, principally by an action for separate maintenance. See Sayre, A Reconsideration of Husband's Duty To Support and Wife's Duty To Render Services, 29 Va. L. Rev. 857, 859 (1943). Where the husband has breached his agreement after divorce, however, the wife's support rights rest solely on the contract. Apart from exceptional cases, judicial powers cannot be invoked for any other purpose but that of enforcing the spouses' agreement.

7 Haas v. Haas, 298 N.Y. 69, 80 N.E. 2d 337 (1948) (containing an exhaustive treatment of the New York cases); Kyff v. Kyff, 286 N.Y. 71, 35 N.E. 2d 655 (1941). And see Vock v. Vock, 365 Ill. 432,6 N.E. 2 d 843 (1937). 
money is squandered, ${ }^{8}$ have no application after a divorce. The separation agreement deals solely with the spouses' legal obligations while they remain married; the divorce agreement is concerned with post-divorce obligations and is a substitute for the alimony and property aspects of the divorce decree. Only the divorce agreement is discussed here; related problems in the law of separation agreements are noted only incidentally.

For a variety of reasons, among them the uncertain legal status of the divorce agreement, cautious lawyers have long resorted to the practice of providing either for judicial approval of the agreement or its actual incorporation into the divorce decree. ${ }^{9}$ Gift and income tax laws have strengthened this practice. ${ }^{10}$ The legal consequences of submitting the agreement to the courts for judicial approval or its actual incorporation into the divorce decree are significant. This Comment represents an attempt to appraise the merits of this practice and the problems to which it has given rise in the light of the corresponding advantages gained or lost through reliance on the agreement alone. The conclusions arrived at provide a basis for considering the overall effectiveness of the divorce agreement as a device for settling alimony and property problems. Following a discussion of the agreement's status in the divorce court, two principal situations are noted: (1) where the original settlement is subsequently attacked as invalid; and (2) where one of the parties seeks to modify the agreement because of changed circumstances. Conflict of laws problems in these areas are also analyzed.

\section{I}

A majority of courts state that their power to pass upon the problems of alimony and property settlement in a divorce suit cannot be derogated by an agreement of the parties. ${ }^{11}$ Judicial justifications for this view are found in the

${ }^{8}$ See, e.g., In Re Young's Estate, 319 IIl. App. 513, 49 N.E. 2d 742 (1913) (provision of separation agreement embodied in separate maintenance decree held void although wife had received $\$ 10,000$ in lieu of all marital support claims); Siebert v. Suhy, 315 Ill. App. 147, 42 N.E. 2d 636 (1942) ( $\$ 15,000$ cash payment to wife held ineffective to release husband of his duty of support); Kyff v. Kyff, 286 N.Y. 71, 35 N.E. 2d 655 (1941). The lump sum type of separation agreement is held to offend Section 15 of the New York Dom. Rel. Law which provides that "(A) husband and wife cannot contract . . . to relieve the husband from his liability to support his wife." See Arbitration Provisions in New York Separation Agreements, 1 Syracuse L. Rev. 128 (1949). The most familiar justification for these cases is that a contrary result "would often ... impress the burden of . . . support . . . upon the public," rather than upon the husband where it rightfully belongs, In re Young's Estate, 319 Ill. App. 513, 517, 49 N.E. 2d 742, 744 (1943). The English courts have not gone to such lengths. See Mills v. Mills [1940] P. 124 (wife's contention that a court order approving a lump sum settlement was invalid rejected as constituting an "extravagant view of public policy").

- See Lindey, Separation Agreements 370 et seq. (1937). At least two courts have even stated that agreements withheld from the divorce tribunal are subsequently unenforceable. See Lasprogato v. Lasprogato, 127 Conn. 510, 513, 18 A. 2d 353, 355 (1941); Maisch v. Maisch, 87 Conn. 377, 383, 87 Atl. 729, 730 (1913). And see note 37 infra.

${ }^{10}$ See text and note at note 55 infra.

" See, e.g., Gillespie v. Gillespie, 242 P. 2 d 837 (Ariz., 1952); Elliott v. Dunham, 191 Okla. 395, 130 P. 2d 534 (1942); Hughes v. Hughes, 173 Va. 293, 4 S.E. 2d 402 (1939). Nor does it 
mandatory language of alimony statutes investing divorce tribunals with authority to decree an "equitable alimony award"12 and in the common-law doctrine that contracts between husband and wife are to be closely scrutinized.13 Agreements may be set aside, it is said, even where fraudulent conduct is not involved. ${ }^{14}$ In Marshall v. Marshall ${ }^{15}$ for example, the spouses entered an agreement whereby the husband promised to pay $\$ 80$ per month for the support of his child in lieu of all claims by the wife for the support of either herself or the child. The divorce court, disregarding the agreement, awarded $\$ 1000$ in gross alimony to the wife together with $\$ 80$ per month for the support of the child. Relying on the agreement, the husband permitted the divorce action judgment to go against him by default. His later attempt to have the divorce decree set aside was unsuccessful. Regardless of the spouses' agreement, the law is well

make any difference what type of agreement is involved; the courts do not usually distinguish between an agreement's property and support provisions for this purpose. See Herrick v. Ferrick, 319 Ill. 146, 149 N.E. 820 (1925); Adler v. Adler, 373 Ill. 361, 371, 26 N.E. 2d 504, 509 (1940). The English cases are in accord. Tulip v. Tulip, [1951] 2 All E.R. 91; Bennett v. Bennett, [1951] 1 All E.R. 1088. The California courts, however, hold that a property settlement agreement is binding upon them in the absence of fraud. Hogarty v. Hogarty, $188 \mathrm{Cal}$. 625, 206 Pac. 79 (1922).

The English cases are based primarily on an interpretation of a provision now found in Section 25 of the Matrimonial Causes Act of 1950 which provides that, "[T] pronouncing a decree for divorce or for nullity of marriage inquire into the existence of antenuptial or post-nuptial settlements made by the parties whose marriage is the subject of the decree, and may make such orders with reference to the application of the whole or any part of the property settled either for the benefit of the children . . or . . . the parties . . as the court thinks fit." The courts have consistently refused to uphold any contract which contains a stipulation barring the wife from applying to the court either for increased maintenance or alimony. See Bennett v. Bennett, [1951] 1 All E.R. 1088; Hyman v. Hyman, [1929] A.C. 601. Consult Hogg, Separation and Maintenance Deeds, 15 Conv. 311 (1951); Separation Agreements and Divorce Court Jurisdiction, 211 L.T. 150 (1951).

12 See, e.g., Elliott v. Dunham, 191 Okla. 395, 130 P. 2d 534 (1942). The one-sided character of this argument has been well stated by the Wyoming court: "[S]uch contracts have been disregarded. ... In doing so, the courts seem to ... (base their decisions) upon the fact that the statute gives them power to fix ... alimony and that such contracts are advisory only, thus relegating the power to contract, also given by statute, into a secondary position." Rinehart v. Rinehart, 52 Wyo. 363, 371, 75 P. 2d 390, 392 (1938).

${ }^{13}$ This doctrine has been carried to extreme lengths in cases dealing with separation agreements, the theory being that the wife is under the "power and domination" of the husband and must conclusively be presumed to have acted under his authority. Ireland v. Ireland, 43 N.J. Eq. 311, 12 Atl. 184 (1888). Accord: Dennison v. Dennison, 98 N.J. Eq. 230, 130 Atl. 463 (1925) (divorce agreement). Under this rubric, the fairness of the agreement must be established by the husband. Some courts have cast the burden on the husband by using a rather lop-sided confidential relation rationale. Cheuvront v. Cheuvront, 54 W.Va. 171, 46 S.E. 233 (1903). A few courts have drawn an explicit distinction between divorce and separation agreements, stating that fairness need not be affirmatively established in the case of divorce agreements. See Rinehart v. Rinehart, 52 Wyo. 363, 75 P. 2d 390 (1938). Most courts, however, maintain that neither "fairness" nor "unfairness" will be presumed in either type of agreement, and that the burden of proof is upon the party trying to establish one or the other. E.g., In re Pierce's Estate, 123 Pa. Super. 171, 187 Atl. 58 (1936).

14 See authorities cited note 11 supra.

${ }^{15} 236$ S.W. 378 (Kan. City Ct. App., 1922). 
settled that parents cannot by contract bind the divorce court in child custody and support matters. ${ }^{16}$ After stating this rule and disregarding the agreement to the extent it governed the child's rights, the court reasoned that the wife's bad faith in respect of her own claims was also immaterial, as the agreement's terms were equally advisory in both cases. In its latter aspect, the Marshall holding is extreme. Aside from cases involving children, the instances in which an agreement has been invalidated in the divorce court almost always involve overreaching conduct resulting in unfairness or actual fraud. ${ }^{17}$

A minority of jurisdictions have held that agreements are binding upon the parties in the divorce court in the absence of special circumstances, such as "extreme unfairness" or actual fraud. ${ }^{18}$ In practice, however, the agreement's status is no different than that in the majority of jurisdictions where the court will rarely substitute its discretion for that of the parties unless overreaching conduct is shown. The leading case in the minority line of authority is Gahusha v. Galusha, ${ }^{19}$ in which the husband agreed to pay his wife $\$ 100$ per month in lieu of all other support or alimony claims. The wife then brought a divorce action requesting $\$ 250$ per month alimony. The trial court, feeling that $\$ 100$ per month was inadequate, granted the wife's request. The Court of Appeals of New York reversed on the ground that the wife had failed to allege facts justifying the court in setting the agreement aside. The degree to which the Galusha holding establishes a barrier to the exercise of the divorce court's discretion in awarding alimony in conflict with the divorce agreement, however, is problematical. Sig-

${ }^{16}$ E.g., Johns v. McNabb, 247 S.W. 2d 640 (Mo., 1952); Worthington v. Worthington, 218 Ala. 80, 117 So. 645 (1928). Compare Eberhart v. Eberhart, 153 Minn. 66, 189 N.W. 592 (1922) (wife denied right to collect arrearages due to herself and child where she breached agreement's custody provisions).

${ }^{17}$ E.g., Cameron v. Cameron, 85 Cal. App. 2d 22, 192 P. 2d 89 (1948) (despite provisions which, when considering husband's circumstances, appeared reasonable, agreement set aside due to husband's inequitable conduct in forcing a divorce in order that he could remarry); Wolff v. Wolff, 134 N.J. Eq. 8, 34 A. 2d 150 (1943) (complete release of wife's right to alimony induced by husband's fraud); Davis v. Davis, 49 Cal. App. 2d 239, 121 P. 2d 523 (1942) (agreement invalidated where wife received less than $\frac{1}{3}$ of spouses' jointly accumulated property and no alimony); Lister v. Lister, 86 N.J. Eq. 30, 97 Atl. 170 (1916) (complete release of wife's alimony rights in return for small lump sum payment where wife had no other means of support). Compare Ross v. Ross, 103 Kan. 232, 173 Pac. 291 (1918) (agreement upheld where wife's provisions reasonably adequate).

The degree of overreaching or inequitable conduct the divorce court will tolerate before setting an agreement aside seems to be greater in the case of wives. Petty v. Petty, $147 \mathrm{Kan}$. 342, 76 P. 2d 850 (1938); cf. Krug v. Krug, 81 Wash. 461, 142 Pac. 1136 (1914). But aside from the apparent reasonableness of the agreement to both spouses, agreements have also been set aside where one spouse's conduct has been particularly inequitable. See Taylor v. Taylor, 26 N.Y.S. 2d 71 (S. Ct., 1941) (wife's adultery grounds for granting divorce).

${ }^{18}$ See, e.g., Belcher v. Belcher, 242 Ky. 54, 45 S.W. 2d 841 (1932) (existence of agreement providing that wife should not hold husband responsible for her support and "in case she (sues) for divorce," would request no alimony, upheld); Lee v. Lee, 55 Mont. 426, 178 Pac. 173 (1919); cf. Cobb v. Cobb, 211 N.C. 1216, 189 S.E. 479 (1931). See also, Rinehart v. Rinehart, 52 Wyo. 363,75 P. $2 d 390$ (1938) and cases there cited.

19116 N.Y. 635,22 N.E. 1114 (1889). 
nificantly, Mrs. Galusha was later successful in her attempt to rescind, ${ }^{20}$ and, with the agreement removed, was then free to apply for alimony incident to her divorce action..$^{21}$

Apart from the agreement's status in the absence of fraud or unfairness, the courts are unanimously agreed that the agreement will be set aside if it tends to facilitate the procurement of a divorce. ${ }^{22}$ An agreement not to contest the divorce action or to withhold a valid defense will usually vitiate the entire contract, as the legal and illegal portions of the agreement are ordinarily inseparable. ${ }^{23}$ The same has been held of an agreement to pay the wife's counsel fees in the event of divorce. ${ }^{24}$ Although the line at which smart bargains become collusive bribes is anything but clear, ${ }_{2}^{25}$ arrangements by which one party is to obtain substantial benefits solely as an inducement to secure a divorce are similarly invalid. ${ }^{26}$ Illegality also results from entering an agreement at a time when

${ }^{20}$ Galusha v. Galusha, 138 N.Y. 272, 33 N.E. 1062 (1893).

${ }^{21}$ In the absence of divorce court action, the question of the post-divorce status of a separation agreement which makes no reference to divorce but which contains a clause providing for the wife's support and maintenance is determined by the spouses' intentions. E.g., Fabrizio v. Fabrizio, 316 Mass. 343, 55 N.E. $2 d 604$ (1944). Many, if not most, courts have been reluctant to hold that the separation agreement has been superseded and the wife's rights to alimony waived where the wife has relied on the agreement and requested no alimony. E.g., Witt v. Witt, 277 Ky. 592, 126 S.W. 2d 1114 (1939); Clark v. Fosdick, 118 N.Y. 7, 22 N.E. 1111 (1889). Other courts have stated and at times blindly followed a rebuttable presumption that the spouses' separation agreement was meant to be abrogated by the divorce decree. Calkins v. Calkins, $155 \mathrm{Kan} .43,122$ P. 2d 750 (1942). In a recent Kansas case, the presumption referred to was erroneously confused with res judicata doctrine to invalidate a divorce agreement which had not been submitted to divorce tribunal. Mitchell v. Mitchell, $171 \mathrm{Kan}$. 390, 233 P. 2d 517 (1951), aff'd, 239 P. 2d 979 (Kan., 1952). See note 37 infra.

22 E.g., Brown v. Brown, 8 Cal. App. 2d 364, 47 P. 2 d 352 (1935); Jones v. Jones, 325 Mo. 1037,30 S.W. $2 d 49$ (1930). The English courts have even held that an agreement may, under some circumstances, constitute connivance at the wife's subsequent adultery. See Greenwood v. Greenwood, [1937] 3 All E.R. 63.

${ }^{23}$ Law v. Law, $186 \mathrm{Ga} .113$, 197 S.E. 272 (1938) (contract whereby wife acknowledged receipt of $\$ 4000$ in full settlement in which parties agreed that either could at any time bring uncontested divorce action held void and no bar to wife's alimony requests); Hood v. Roleson, 125 Ark. 30, 187 S.W. 1059 (1916). Consult Lindey, op. cit. supra note 1, at 379-81.

24 McCahan v. McCahan, 47 Cal. App. 173, 190 Pac. 458 (1920). The courts are not in accord as to the validity of a contract in which the wife waives her right to counsel fees in the event of divorce. In some cases, such a contract has been held valid and enforceable. Worman v. Worman, 118 Fla. 471, 159 So. 677 (1935); Melson v. Melson, 151 Md. 196, 134 Atl. 136 (1926). In others, it has been regarded as illegally tending to facilitate a divorce. Banner v. Banner, 180 Mo. App. 396, 171 S.W. 2 (1914). Occasionally, a court will interpret such a provision out of existence. Smith v. Smith, 127 Misc. 764, 217 N.Y. Supp. 3 (S. Ct., 1926).

${ }^{25}$ Compare Brown v. Brown, 8 Cal. App. 2d 364, 47 P. $2 d 352$ (1935), with Abeles v. Abeles, 197 Misc. 913, 96 N.Y.S. 2d 423 (S. Ct., 1950); and Hill v. Hill, 23 Cal. 2d 82, 142 P. 2d 417 (1943), noted in 31 Cal. L. Rev. 596 (1943).

25 Yates v. Yates, 183 Misc. 934, 51 N.Y.S. 2d 135 (S. Ct., 1944); Brown v. Brown, 8 Cal. App. 2d 364, 47 P. 2d 352 (1935). The mere existence of a divorce agreement, of course, will never establish collusion. Additional factors are needed: See Annotation; 2 A.L.R. 699, 708 et seq. (1919). 
divorce or separation is not immediately contemplated, ${ }^{27}$ or, in some jurisdictions, where the separation has not already occurred..$^{28}$

With respect to the question of whether or not the wife has to make restitution of benefits acquired up to the time of the divorce, the consequences of invalidity are the same in all of the situations mentioned. Perhaps no court has held an offer to make restitution a condition precedent to the wife's action either in rescinding directly or as an incident to the divorce proceeding; ${ }^{29}$ and she has never been called upon to return payments intended solely for her support prior to the divorce. ${ }^{30}$ Collateral property benefits, however, must ordinarily be restored, ${ }^{31}$ although an exception to this rule exists in any case where the property in question has been dissipated and tracing turns out to be impossible..$^{32}$ While a distinction between actions of rescission for fraud and actions to declare a contract invalid has sometimes been drawn for the purpose of determining whether benefits need be returned in ordinary contract cases ${ }^{33}$ the distinction has not been applied in the divorce agreement area. In both of these situations, ${ }^{34}$ as well as where an agreement is set aside because of a breach of a material term, ${ }^{36}$ the rules governing return of benefits are the same. Regardless of the ground upon which the divorce agreement is set aside, the wife is thereafter free to apply for the usual measure of alimony, although the amount awarded will ordinarily reflect what she has already received. An agreement's executory provisions are, of course, abrogated either by divorce court action in setting an agreement aside or by the wife's successful attempt to rescind or cancel directly. ${ }^{36}$

${ }^{27}$ See, e.g., Whedon v. Whedon, 247 App. Div. 463, 286 N.Y. Supp. 664 (1936); Blackburn v. Blackburn, $208 \mathrm{Ky} .690$, 271 S.W. 1037 (1925).

${ }^{28}$ Consult Lindey, op. cit. supra note 1 , at 44 et seq. The agreement will also be held invalid if the spouses were not moved to enter it for adequate reasons. Felton v. Felton, 123 Conn. 564, 196 Atl. 791 (1938). A mere willingness to live apart at the time the agreement is negotiated is not enough. See Archbell v. Archbell, 158 N.C. 408, 74 S.E. 327 (1912); with which compare Murphy v. Murphy, $308 \mathrm{Ky} .194,213$ S.W. 2d 601 (1948) (indicating that a mutual desire for future celibacy is sufficient). Invalidity may also result from a failure to comply with applicable statutory formalities. Archbell v. Archbell, 158 N.C. 408, 74 S.E. 327 (1912).

29 See, e.g., Russo v. Russo, 205 La. 582, 18 So. $2 d 318$ (1944), noted in 19 Tulane L. Rev. 290 (1945).

${ }^{30}$ E.g., Verdier v. Verdier, 36 Cal. 2d 241, 223 P. $2 d 214$ (1950), noted in 24 So. Calif. L. Rev. 211 (1951).

${ }^{21}$ E.g., Russo v. Russo, 205 La. 582, 18 So. $2 d 318$ (1944); McAllen v. Hodge, 94 Minn. 237, 102 N.W. 707 (1905). And see Focht v. Wakefield, 145 Neb. 568, 17 N.W. 2d 627 (1945). Compare Silverman v. Silverman, 95 S.W. 2d 1237 (St. Louis Ct. App., 1936).

a Hollingshead v. Hollingshead, 91 N.J. Eq. 261, 110 Atl. 19 (1920); Zysman v. Zysman, 140 Misc. 617, 251 N.Y. Supp. 355 (S. Ct., 1931).

${ }^{23}$ Rest., Contracts $\$ \S 480,598-609$ (1933).

"See authorities cited note 31 supra.

${ }^{35}$ See Verdier v. Verdier, 36 Cal. 2d 241, 223 P. $2 d 214$ (1950), noted in 24 So. Calif. L. Rev. 211 (1951).

${ }^{36}$ See Mitchell v. Mitchell, 263 Ill. 165, 104 N.E. 1037 (1914). In some cases, it has even been held that the wife forfeits pre-divorce contract arrearages if she elects to sue for divorce 
The status of an agreement which has been withheld from the divorce tribunal when judicial action has been taken in violation of its terms is not clear. With a single exception, ${ }^{37}$ the problem has only arisen where the husband attempts to set aside a default caused by his reliance upon the wife's promise to accept no more than has been agreed upon as alimony. Relief has usually been denied, but the answer depends in each state upon particular procedural laws. Most of the cases granting relief involve special circumstances. ${ }^{38}$ In Rinehart v. Rine$h a r t,{ }^{39}$ for example, following the institution of the wife's divorce action, the parties entered into a contract on the faith of which the husband neglected to defend, allowing judgment to go against him by default. He relied particularly on a stipulation that the wife would accept $\$ 500$ in cash and $\$ 60$ per month, together with all other property the spouses possessed "in full of all alimony." Judgment was entered for $\$ 100$ per month alimony, the husband first learning of this after the period for an appeal had run on the occasion of the wife's

before first suing for the husband's breach of contract. Randolph v. Field, 165 App. Div. 278, 150 N.Y. Supp. 822 (1914). Contra: Brieterman v. Brieterman, 239 App. Div. 709, 268 N.Y. Supp. 628 (1941).

${ }_{37}$ The recent Kansas case, Mitchell v. Mitchell, 171 Kan. 390, 233 P. $2 d 517$ (1951), aff'd, 239 P. 2 d 979 (Kan., 1952), expressly states that any divorce agreement not submitted to and approved by a divorce tribunal having power to award alimony is subsequently unenforceable. The spouses, in contemplation of a divorce, entered an agreement providing for periodic support payments by the husband. On March 3, 1945, they were divorced in an Oklahoma court, the Oklahoma decree making no reference to the agreement. The payments were duly made for two months, but, in consequence of the parties' remarriage on May 3, 1945, were then stopped in conformance with the contract. On September 21, 1946, a Missouri divorce decree was entered which, like its Oklahoma predecessor, failed to mention the spouses' agreement. Under the circumstances indicated, the contract called for a resumption of support payments. Seeking to enforce the agreement, the wife brought action in Kansas. The court, relying on the doctrine that a separation agreement not referred to in the divorce decree is presumed to have been superseded, held that the divorce agreement, not having been approved in the Missouri proceedings, was no longer enforceable. The court buttressed its result with the "well recognized general rule that where matters could have been adjudicated in an action between the same parties, the judgment in the earlier action will be res judicata of all those matters in a subsequent action." Ibid., 239 P. 2 at 980 . The argument that the laws and judicial decrees of both Missouri and Oklahoma permitting the spouses to withhold their contract from the divorce court without rendering it unenforceable could not constitutionally be disregarded was dismissed with the statement that no full faith and credit problem was involved. The many questionable aspects of the case can undoubtedly be explained by the court's desire to reach an equitable result. The fact that the spouses' agreement would everywhere have been held to be void upon the parties's reconciliation following the Oklahoma divorce was apparently not suggested to the court. Although otherwise explainable, the Mitchell case appears to be the first square holding that agreements withheld from a divorce tribunal are subsequently unenforceable regardless of the parties' intentions. The situation where one spouse is indebted to the other at the time of the divorce, and a decree adjusting property rights is entered, is clearly distinguishable. Under these circumstances, a presumption that the divorce decree has taken the pre-existing indebtedness into account is properly applicable. See Mayfield v. Gray, $138 \mathrm{Kan}$. 156, 23 P. 2d 498 (1933).

${ }^{38}$ See Wamberg v. Wamberg, 111 Kan. 248, 206 Pac. 889 (1922). Marshall v. Marshall, 236 S.W. 378 (Kan. City Ct. App., 1922); Cross v. Cross, 98 Wash. 651, 168 Pac. 168 (1917). Cf. also, Hobbs v. Hobbs; 72 Colo. 190, 210 Pac. 398 (1922).

3952 Wyo. 363,75 P. 2 d 390 (1938). 
garnishment of his salary. Moving to set aside the default, he alleged the existence of the agreement and also his wife's desertion. The Wyoming Supreme Court allowed the motion, holding that public policy demanded that such agreements be enforced. ${ }^{40}$ That the holding was not a sweeping affirmation of the binding effect of divorce agreements in all situations, however, is clear from the recent opinion in Buchler v. Buchler, ${ }^{41}$ where the Rinehart case was confined to its exact facts. In both opinions, the Wyoming Court made it clear that the Rinehart holding would be limited to the situation where the husband, relying on the agreement, allowed the divorce judgment to go by default although he possessed a substantive defense-desertion. Nor, judicial pronouncements notwithstanding, ${ }^{42}$ is it likely that a husband would be allowed to sue for breach of contract where he was unable to have the alimony decree itself set aside. Such an action would probably be regarded as an inadmissible collateral attack on the divorce decree. ${ }^{43}$ Nevertheless, authority in the other direction is available by analogy, ${ }^{44}$ and a dictum in a recent California case ${ }^{45}$ asserts that the action might be maintained. As a fraud action for damages cannot be predicated on a mere breach of contract, ${ }^{46}$ the tort remedy would appear to be unavailable. From the standpoint of the injured spouse, the parties' agreement has seemingly been destroyed by the divorce decree.

II

The post-divorce status of an agreement which has received divorce court: approval depends primarily on whether or not the agreement has become

40 " $[\mathrm{L}] \mathrm{aw}$ cannot . . . ignore changed conditions and proceed from premises which are no longer sound. . . Hence decisions founded upon the assumption that a wife is under the dominance of her husband, when that assumption is unrelated to present day realities, 'ought not to be permitted to prescribe a rule of life." "Ibid., at 380 and 396.

4165 Wyo. 452, 202 P. $2 d 670$ (1949).

12 See Innes v. McColgan, 47 Cal. App. 2d 781, 118 P. 2d 855 (1941).

${ }^{43}$ Consult Rest., Judgments $\S 45$, Comment c; $\S 58$, Comment c (1942); 31 Am. Jur., Judgments $\$ 594(1940)$. That the suggested outcome is correct is indicated by the fact that the only capacity in which the husband has thus far been successful in collecting for his wife's breach of contract is as counter-claimant to the better-half's action for past-due support. E.g., Moller v. Moller, 121 N.J. Eq. 175, 188 Atl. 505 (1936) (husband allowed to counterclaim for breach of wife's covenant to release dower).

While the cases are not in complete accord, it is generally held that the wife's failure to allow the husband access to his children in breach of the agreement will entirely defeat the wife's action to recover arrearages. Cole v. Addison, 153 Ore. 688, 58 P. 2d 1013 (1936); Duryea v. Bliven, 122 N.Y. 567, 25 N.E. 908 (1890). Compare Stuart v. Stuart, 133 F. $2 d 411$ (App. D.C., 1913). Some cases have reached an opposite result on the theory that the child's rights cannot be affected by the wife's actions. Zirkle v. Zirkle, 202 Ind. 129, 172 N.E. 192 (1930); Maxwell v. Boyd, 123 Mo. App. 334, 100 S.W. 540 (1907).

${ }^{44}$ See Griffith v. Bank of New York, 147 F. 2d 899 (C.A. 2d, 1945) and cases there cited (damage action allowed for trustee's breach of fiduciary obligation in procuring plaintiff's consent to judgment). Consult 31 Am. Jur., Judgments $\$ \$ 615,654$ (1940).

${ }_{45}^{4}$ Innes v. McColgan, 47 Cal. App. 2d 781, 118 P. 2d 855 (1941).

${ }^{46} 1$ Williston, Contracts $\$ 60 \mathrm{AA}$ (rev. ed., 1936). 
"merged" into the divorce decree. In determining whether a merger has taken place, the intention of the parties is often said to be of fundamental importance. ${ }^{47}$ In practice, however, the difficulties inherent in determining intention have led to the adoption of more objective standards, and some cases appear to ignore the spouses' intention altogether. ${ }^{48}$ The factor most frequently emphasized is the manner in which the agreement is referred to in the decree. Thus, where the agreement has only been "approved, ratified, and confirmed," perhaps a majority of courts have held that that contract has not been superseded. ${ }^{99} \mathrm{~A}$ contrary result has usually obtained, however, where the agreement has been expressly adopted and made a part of the decree, although the courts are not in harmony as to whether the agreement must be set out in full or whether mere "incorporation by reference" will suffice. ${ }^{50}$ Nor are the cases agreed on the effect of an order that the contract's provisions "be forthwith carried out." In addition to the language of the divorce decree, the courts have also considered whether or not the agreement mentioned in the decree was merely a stipulation agreed upon for the purpose of the divorce proceeding. ${ }^{52}$ If the contract has had an independent existence prior to the divorce, a merger will not readily be found..$^{53}$ The merger cases, however, cannot always be explained in terms of the standards referred to. Courts have often been willing to

${ }^{47}$ E.g., Gillespie v. Gillespie, 242 P. 2d 837, 839 (Ariz., 1952) and cases there cited. See also, Note, 26 St. John's I. Rev. 164 (1951); Control of Post-Divorce Level of Support by Prior Agreement, 63 Harv. L. Rev. 337, 338 (1949).

${ }^{48}$ E.g., Howarth v. Howarth, 81 Cal. App. 2d 266, 183 P. 2 d 670 (1947); Elliott v. Dunham, 191 Okla. 395, 130 P. 2d 534 (1942). It is doubtful, however, whether any court would fail to give effect to an express provision that the contract should survive the divorce decree. See Hough v. Hough, 26 Cal. 2d 605, 612, 160 P. 2d 15, 18 (1945).

19 Allen v. Allen, 196 Okla. 36, 162 P. 2 d 193 (1945); Tieso v. Tieso, 155 P. 2 d 659 (1945); McWilliams v. McWilliams, 110 Colo. 173, 132 P. 2d 966 (1942); Elliott v. Dunham, 191 Okla. 395, 130 P. 2d 534 (1942); Welsh v. Welsh, 93 S.W. 2d 264 (St. Louis Ct. App., 1936); Moore v. Crutchfield, 136 Va. 20, 116 S.E. 482 (1923). Nor will merger occur where the divorce decree is void. Watton v. Watton, 76 Cal. App. 2d 669, 173 P. $2 \mathrm{~d} 867$ (1946).

${ }^{50}$ That mere incorporation by reference is insufficient, see Shogren v. Superior Court, 93 Cal. App. 2d 346, 209 P. 2d 108 (1949); McWilliams v. McWilliams, 110 Colo. 173, 132 P. 2d 966 (1942); Moore v. Crutchfield, 136 Va. 20, 116 S.E. 482 (1923) (containing an excellent discussion of the authorities). Contra: Hough v. Hough, 26 Cal. 2d 605, 160 P. 2d 15 (1945), noted in 19 So. Calif. L. Rev. 70 (1945); Reynolds v. Reynolds, 53 R.I. 326, 166 Atl. 686 (1933) (merger declared where agreement "incorporated .... as fully and completely as if herein referred to in full"). See also, Gillespie v. Gillespie, 242 P. 2d 837 (Ariz., 1952). If the decree makes no reference to the agreement whatever, a finding that merger has occurred is highly unlikely. See Allen v. Allen, 196 Okla. 36, 162 P. 2d 193 (1945).

51 Compare Plummer v. Superior Court, 20 Cal. App. 2d 158, 124 P. 2 d 5 (1942), with Petry v. Superior Court, 46 Cal. App. 2d 746, 116 P. 2d 954 (1941). And see, Elliott v. Dunham, 191 Okla. 395, 130 P. 2d 534 (1942).

32 Allen v. Allen, 196 Okla. 36, 162 P. 2d 193 (1945); Holmes v. Holmes, 186 Ark. 251, 53 S.W. 2d 226 (1932).

ss See authorities cited note 52 supra. 
deviate from the usual rules governing the presence or absence of merger where the equities of a particular case seemed to demand it. ${ }^{54}$

Merger problems have recently been highlighted by the Supreme Court's decision in Harris v. Commissioner, ${ }^{55}$ establishing the gift tax advantage obtained through incorporation in any case where a substantial lump sum or limited payment form of agreement is employed. ${ }^{66}$ While the precise limits of the Harris doctrine are as yet unsettled, ${ }^{57}$ the Harris case itself seems to make clear that an "incorporation" sufficient for tax savings is not necessarily an incorporation sufficient to effectuate a merger for state law purposes. ${ }^{58}$ The implications of such cases as Harris may be significant to those seeking an escape from gift and estate $\operatorname{tax}^{59}$ burdens, but they are not reliable guides to an understanding

${ }^{54}$ E.g., Evens v. Evens, 55 S.D. 482, 226 N.W. 725 (1929) (guarantors' contention that guaranty of support payments under divorce agreement had become merged in the decree rejected because the doctrine of merger "will not be carried further than the ends of justice require").

ss 340 U.S. 106 (1950). The Harris case came somewhat as a surprise. Only five years earlier, the Court had held that a transfer pursuant to a premarital agreement in consideration of the relinquishment of marital property rights constituted a taxable gift, as not falling within the gift tax exemption of all transfers made for an "adequate and full consideration in money or money's worth." Merrill v. Fahs, 324 U.S. 308 (1945) (interpreting Int. Rev. Code $\$ 1002$, 26 U.S.C.A. $\$ 1002$ [1948]). See also, Comm'r v. Wemyss, 324 U.S. 303 (1945). The Court reached the result in the Fahs case by reading into the gift tax law a provision in the estate tax law that "a relinquishment or promised relinquishment of dower, curtesy ... or of other marital rights in the decedent's property or estate, shall not be considered to any extent a consideration in money or money's worth." Int. Rev. Code \$ 812(b), 26 U.S.C.A., § 812(b) (1948). The Harris decision expanded this in pari materia construction. As the estate tax, law requires that a taxable transfer in consideration of the relinquishment of marital property rights must be based on a "promise or an agreement," the Harris opinion is chiefly concerned with whether or not a settlement incorporated (by reference) into a divorce decree is a transfer based on a "promise or an agreement." Concluding that it was not, the Court held that any transfer in "discharge of a legal obligation" as evidenced by the agreement's incorporation into a divorce decree was not a taxable gift.

${ }_{56}$ That the distinction between nonincorporated and incorporated agreements for gift tax purposes, as established by the Harris case, should have been criticized is not surprising. See Pedrick, The Gift Tax Jurisdiction of the Divorce Court, 45 III. L. Rev. 177, 181 et seq. (1951); Postmarital Settlements and the Gift Tax, 19 Univ. Chi. L. Rev. 46 et seq. (1951).

${ }^{57}$ For an exhaustive study of the problems involved, consult the articles cited note 56 supra. And see Vonderheit, Income-Tax and Gift-Tax Aspects of Divorce, 31 Ore. L. Rev. 1 (1951).

${ }^{88}$ The majority themselves recognized this: "We ... think that the gift tax statute is concerned with the source of rights, not with the manner in which rights ... may be enforced. Remedies for enforcement will vary from state to state. It is 'the transfer' of the property with which the gift tax statute is concerned, not the sanctions which the law supplies to enforce transfers." 'Harris v. Comm'r, 340 U.S. 106, 111 (1950). The majority regarded as immaterial a provision that the agreement was to subsist independently despite its incorporation by reference in the decree. Ibid. Compare the view of the four dissenting justices, ibid., at 119 et seq.

${ }^{69}$ The Harris rationale seems applicable to both estate and gift tax cases. Such decisions as Myer's Estate v. Comm'r, 110 F. 2d 367 (C.A. 2d, 1940) may now be averted by incorporation of the agreement into the decree. This case held that, in the absence of court order, pastdue support and the commuted value of additional future payments were properly disallowed as deductions from the gross value of the husband's estate. To the extent that payments are 
of state divorce law. Similar considerations apply to the income tax cases requiring a judicial decree before alimony payments can be made taxable income to the wife. ${ }^{60}$

The importance of merger is clearly seen where factors such as fraud and duress have operated to induce a divorce agreement later attacked as invalid. Where merger has taken place, the resulting decree stands on the same footing as any divorce decree containing alimony and property items freely determined by the court. Equitable rules governing relief from judgments are fully applicable. However, if the embodied agreement provides for a series of periodic payments, relief will ordinarily be afforded in the exercise of the divorce court's continuing jurisdiction. ${ }^{61}$ Incorporated lump sum agreements, being final, have proved more troublesome. If either spouse has been guilty of misrepresentation or concealment, perhaps a majority of cases have held that the injured party is entitled to an injunction against the enforcement of the decree based on the spouses' agreement and affirmative equitable relief barring the presence of spe-

made under an agreement for the satisfaction of decedent's obligation of supporting his children, however, incorporation would seem to be unnecessary. See Helvering v. U.S. Trust Co., 111 F. 2d 576 (C.A. 2d, 1940).

${ }^{60}$ Generally speaking, there are five principal requirements in order that an agreement's payments may be taxed as income to the wife and deducted by the husband. First, the parties must be divorced or legally separated. Thus, if payments are made pursuant to a support order rather than a decree of separate maintenance, the husband may not deduct them. Kalchthaler v. Comm'r, 7 T.C. 625 (1946). Second, the payments must, with a single exception, be periodic, although regularity is not required. See Young v. Comm'r, 10 T.C. 724 (1948). The payments must also be received subsequent to the decree. A nunc pro tunc decree does not satisfy this requirement. Daine v. Comm'r, 168 F. 2d 449 (C.A. 2d, 1948). Again, the payments must be in discharge of a legal obligation arising out of the family relationship. Gratuitous payments not required by a court decree are therefore taxable to the husband. Dautvalter v. Comm'r, 9 T.C. 580 (1947). Finally, the payments must be incident to a divorce or legal separation decree. Brady v. Comm'r, 10 T.C. 1192 (1948). To avoid the problem of establishing whether the agreement is "incident to the decree," it is advisable for income tax purposes to provide for incorporation in all cases. See Vonderheit, Income-Tax and Gift-Tax Aspects of Divorce, 31 Ore. L. Rev. 1, 8 (1951); Surrey and Warren, Federal Income Tax, Cases and Materials 751-69 (1950).

It would now seem desirable, since the adoption of the split-income concept, to dispense with the court-decree requirement, since the parties could have split their incomes had they remained together, or even had they separated, absent a court decree. See Surrey and Warren, Federal Income Taxation, Cases and Materials 757 (1950).

Following the Supreme Court's decisions in Douglas v. Willcuts, 296 U.S. 1 (1935), and Helvering v. Clifford, 309 U.S. 331 (1940), it was thought unconstitutional to tax alimony or support payments as income to the wife, the theory being that Congress had manifested its intention to use its power under the Sixteenth Amendment to the fullest possible extent. The contrary view would now seem to be well settled. Int. Rev. Code $\$ \S 22(\mathrm{k}) ; 23(\mathrm{u}) ; 171 ; 3797$ (17), 26 U.S.C.A. $\S \S 22(\mathrm{k}) ; 23$ (u); $171 ; 3797$ (17) (1948). See also, Mahana v. United States, 88 F. Supp. 285 (Ct. Cl., 1950). The present statutory treatment of alimony was adopted in 1942 to relieve husbands hard pressed by war taxes who frequently found their income taxes after alimony in excess of their net incomes.

${ }^{61}$ Cf. Rose v. Rose, 135 N.J. Eq. 458, 39 A. $2 d 87$ (1944). Consult Rest., Judgments $\$ 5$. Comment f (1942). 
cial factors, such as negligence or laches. ${ }^{62}$ The court will place the parties in the position in which they would have been, absent the fraudulent conduct. ${ }^{63}$ But even in jurisdictions usually granting such relief, a final decree has seldom been set aside to the detriment of a deceased spouse's estate, ${ }^{64}$ or where the time lapse from the rendition of the divorce decree has been considerable. ${ }^{65}$ The cases are largely concerned with whether the misrepresentation involved is "extrinsic" or "intrinsic" within the rule that judgments can be vacated or modified only for "extrinsic fraud." The basic test is whether under all the circumstances the injured party may fairly be said to have had his day in court. ${ }^{67}$ Cases denying relief usually rest on the ground that the misrepresentation in issue does not amount to "extrinsic fraud,"68 that the prior decree is res judicata, ${ }^{69}$ or that the assertion of the requested relief constitutes a collateral attack on the divorce decree..$^{70}$ The character of fraud sufficient to vitiate a judgment must, in any case, be far more flagrant than the "unfairness" or "fraud" required to set aside a divorce agreement in or prior to the divorce proceedings. ${ }^{71}$ Society's interest in the stability of judgments and the courts' desire to prevent "excursions by irate

62 E.g., Glover v. Glover, 242 P. 2d 298 (Utah, 1952); Martin v. Martin, 242 P. 2d 688 (Cal. App., 1952); Dodd v. Postel's Estate, 214 Ind. 39, 14 N.E. 2d 539 (1938); Taylor v. Taylor, 192 Cal. 71, 218 Pac. 756 (1923); Jewel v. Jewel, 71 Colo. 470, 207 Pac. 991 (1922).

${ }^{63}$ See authorities cited note 62 supra. Consult Rest., Judgments $\$ 114$, Comment b (1942).

64 E.g., Kearley v. Hunter, 154 Fla. 81, 16 So. 2d 728 (1944) (relief denied where divorced wife brought action two years after decree became final where both parties had remarried and the husband had subsequently died); Scanlon v. McDevitt, 50 Id. 449, 296 Pac. 1016 (1931). Compare Vragnizan v. Savings Union Bank \& Trust Co., 31 Cal. App. 709, 161 Pac. 507 (1916).

${ }_{65}$ E.g., Isler v. Isler, 149 Ore. 554, 41 P. $2 d 451$ (1935) (ten years); Putnam v. Putnam, 126 Kan. 479, 268 Pac. 797 (1928) (nine years); Uecher v. Thiedt, 133 Wis. 148, 113 N.W. 447 (1907) (five years). Compare Glover v. Glover, 242 P. 2d 298 (Utah, 1952).

${ }^{66}$ While the terms "extrinsic" and "intrinsic" do not indicate a clear distinction in terms of the fraudulent conduct necessary to secure equitable relief against judgments, they are deeply rooted in the case law. United States v. Throckmorton, 98 U.S. 61 (1878). If the fraud is upon the court, i.e., of a nature which prevents the court from rendering the judgment it would have rendered with full knowledge of the facts, the fraud is "extrinsic" and relief will be granted. Fraud is "extrinsic" within this rule where the adversary party has been induced to withhold defenses, or to withdraw from or fail to appear in the action. If the fraud relied upon to invalidate the judgment is merely upon the other party, however, as in the case of perjury, the fraud is "intrinsic" and relief will be denied. The cases are collected in Annotation, 88 A.L.R. 1201 (1934).

${ }^{67}$ Rest., Judgments $\S \S 118,120-24$ (1942).

${ }^{68}$ E.g., Williams v. Williams, 138 Kan. 310, 26 P. 2d 258 (1933); Scanlon v. McDevitt, 50 Id. 449, 296 Pac. 1016 (1931); Putnam v. Putnam, 126 Kan. 479, 268 Pac. 797 (1928).

${ }^{68}$ E.g., Worthington v. Worthington, $218 \mathrm{Ala} .80,117$ So. 645 (1928); Willeard v. Winkleman, 191 Wis. 406, 211 N.W. 137 (1926).

70 Bullock v. Bullock, 131 Wash. 339, 230 Pac. 130 (1924); with which compare Dodd v. Postel's Estate, 214 Ind. 39, 14 N.E. 2d 539 (1938).

71 Compare Pomerance v. Pomerance, 301 N.Y. 254, 93 N.E. 2d 832 (1950), and Verdier v. Verdier, 36 Cal. 2d 241, 223 P. 2d 214 (1950), noted in 24 So. Calif. L. Rev. 211 (1951), with Willeard v. Winkleman, 191 Wis. 406, 211 N.W. 137 (1926). 
ex-wives into the altered domestic realm(s) of ex-husbands," ${ }^{\prime 72}$ overshadow the importance of remedying overreaching conduct except in the most extreme cases. ${ }^{73}$ Similar considerations apply to requested modifications on such grounds as duress or mistake. Nevertheless, the trend of recent case law is unmistakenly in the direction of granting relief on a more liberal basis than in the past. ${ }^{74}$

While the degree of injury required for the invalidation of a merged agreement is greater than in the case of an agreement not fortified by a decree, the chief significance of incorporation lies in the area of available remedies. If the parties' contract has been superseded by a divorce decree, relief against fraud in the form of additional alimony or an increased share of the erring spouse's property can be secured in an equitable action to restrain the enforcement of the decree. If the contract alone has been relied upon, however, no equivalent remedy is available. Although an action for rescission of the agreement would in proper case undoubtedly be entertained, its worth will almost always be nil. Where rescission is sought, a return of the benefits received under the agreement is a necessary concomitant to the maintenance of the action, and no affirmative relief will be granted. ${ }^{75}$ Therefore, in the familiar case of the defrauded wife, the rescission remedy is worthless except in the small minority of jurisdictions permitting post-divorce grants of alimony. ${ }^{76}$ No case has been uncovered in which a rescission action has been attempted under these circumstances. Reformation of an agreement for fraud is, of course, ordinarily not allowed. ${ }^{77}$

Tort actions for fraud present a comparatively circumscribed alternative to an equitable action for relief against the divorce decree in the case of the incorporated agreement and have seldom been employed. Where the contract alone has been relied upon, however, the inefficacy of rescission, due to the scarcity of post-divorce alimony statutes, leaves the tort remedy as the sole form of relief. Only two ${ }^{78}$ of the three cases in which a tort action was attempted granted recovery. The principal disadvantage of the tort remedy seems to lie in the absence of equitable limitations on the wife's ability to maintain it. Although the husband may be guilty of fraud, the wife might not equitably be entitled to any more than she has already received. The case of United States National

72 Glover v. Glover, 242 P. 2d 298, 301 (Utah, 1952).

73 Consult Rheinstein, Cases On Decedent's Estates 925 (1947).

74 See, e.g., Martin v. Martin, 242 P. $2 d 688$ (Cal. App., 1952); Glover v. Glover, 242 P. 2d 298 (Utah, 1952); with which compare Worthington v. Worthington, 218 Ala. 80, 117 So. 645 (1928).

75 See notes 71 and 72 supra and accompanying text. Compare Glover v. Glover, 242 P. 2d 298 (Utah, 1952) (indicating that affirmative relief is available).

${ }^{76}$ See Ill. Rev. Stat. (Smith-Hurd Ann. Supp., 1951) c. 40, 119 ; Mass. Ann. Stat. (1932) c. 208, §34; N.J. Rev. Stat (1937) § 2:50-36.

77 Schoonover v. Schoonover, 172 F. 2d 526 (C.A. 10th, 1949).

78 U.S. Nat'l Bank of Denver v. Bartges, 120 Colo. 317, 210 P. 2d 600 (1949), cert. denied, 338 U.S. 955 (1949), aff'd, 122 Colo. 546, 224 P. 2d 658 (1950); Schoonover v. Schoonover, 172 F. 2d 526 (C.A. 10th, 1949). Compare Weintraub v. Weintraub, 302 N.Y. 104, 96 N.E. 2d 724 (1951). 
Bank of Denver v. Bartges, ${ }^{79}$ in which the tort action was successful, furnishes an illustration of this. The trial court found that the wife had purposely expedited the pre-divorce contract negotiations in order to procure a divorce as rapidly as possible; and that, although adequately represented, her counsel had made no inquiry as to her husband's basis for valuating certain securities concerning which fraud was now claimed. Additional "equities" strengthened the husband's position. ${ }^{80}$ Both parties acted through independent counsel during the entire course of the contract negotiations. Large damages for a violation of "fiduciary confidences" under these circumstances seem anomalous. Gift tax cases in which such transactions are treated on a strictly bargain-and-sale basis appear decidedly more realistic. ${ }^{81}$

Aside from the absence of equitable limitations on the wife's right to maintain a Barlges-type action, two further difficulties should be noted. The first is founded upon the complete lack of precedent in deceit actions for mitigation of damages due to plaintiff's inequitable conduct unconnected with the value of the bargain or property lost as a result of defendant's fraud. Tort law has largely confined its recognition of such conduct to cases involving seduction, alienation of affections, and defamation. ${ }^{82}$ The failure to allow mitigation by the Bariges' court in the only case in which grounds for mitigation were present highlights this difficulty.

The effectiveness of the tort remedy is also affected by the fact that, in many jurisdictions, the measure of damages for fraud is based solely on the plaintiff's out-of-pocket losses..$^{83} \mathrm{~A}$ defrauded wife might conceivably be regarded as having parted with nothing, so that nothing could be recovered. Such a result would be supported both by the traditional conception of alimony as being personal rather than proprietary in nature, ${ }^{84}$ and by its statutory rather than common-law origin. ${ }^{85}$ However, a defrauded wife's right to have alimony deter-

79120 Colo. 317, 210 P. 2d 600 (1949), cert. denied, 338 U.S. 955 (1949), aff'd, 122 Colo. 546, 224 P. 2d 658 (1950).

${ }^{80}$ Thus the wife's damages were payable out of the husband's estate which had been left largely to his children; and it was the wife who desired the divorce in order that she might marry one of the husband's young employees.

8I See the remarks of Disney, J., dissenting in McLean v. Comm'r, 11 T.C. 543,551 (1948). "Can there be any question that these transfers were not actuated by the ordinary donative intent existing between sweethearts?" See also, Estate of Byram v. Comm'r, 9 T.C. 1 (1945); Farid-Es-Sultaneh v. Comm'r, 160 F. 2d 812 (C.A. 2d, 1947).

${ }^{82}$ Consult McCormick on Damages 393, 396, 401, 403, 409 (1935).

83 Under the "out-of-pocket" rule, a defrauded plaintiff is permitted to recover the value he parted with under the misrepresentation, less the value he received under the contract. Smith v. Bolles, 132 U.S. 125 (1889). The "contract" or "loss-of-the-bargain" rule, however, permits recovery for the difference between the value the plaintiff would have received had the misrepresentations been true, and the value actually received. The latter rule is followed in a majority of states. Consult McCormick on Damages 448-454 (1935).

${ }^{84}$ See Shields v. Bosch, 190 Ore. 155, 224 P. 2d 560 (1950) (right to sue for alimony is personal to divorced spouse and does not pass to personal representative).

${ }^{85}$ See Weintraub v. Weintraub, 302 N.Y. 104, 96 N.E. $2 d 724$ (1951). Consult Sayre, op. cit. supra note 6 at 865 . 
mined by the court with full knowledge of all the facts seems to be a substantial loss. This problem has not yet been faced, ${ }^{86}$ as the only jurisdiction in which the tort action was disallowed based its ruling on other grounds; and jurisdictions in which the action has been permitted do not follow the out-of-pocket rule.

The suggestion that tort actions are ill-suited to the divorce agreement area does not mean that a defrauded wife should go remediless. If the spouses' agreement has not been incorporated and the property-owning husband is guilty of fraud, an equitable rescission action (now ordinarily useless to the property-less wife), should be allowed and joined with the right to apply for post-divorce alimony. ${ }^{87}$ Statutes providing for post-divorce alimony, however, should be strictly limited in accordance with equitable doctrines such as laches, negligence, and estoppel.

\section{III}

Perhaps the chief significance of incorporation, aside from the fact that it makes contempt proceedings available for the enforcement of the agreement, ${ }^{88}$ lies in its effect on the possibility of modifying the agreement due to changed circumstances. Where the contract has completely merged in the decree, the court's power to modify alimony payments is in no way affected by the fact that the decree is based upon an agreement. ${ }^{89}$ Payments may thereafter be scaled up

${ }^{86}$ The measure of damages applied in the Bartges case, 120 Colo. 317, 335, 210 P. 2d 600, 609 (1949), the "difference between what . . . (was) received under the fraud induced agreement and what . . . would have (been) received upon a fair ... division of property as is . . mandatory" under Kansas law raises the further question as to the measure of recovery in a jurisdiction where property division is not mandatory or even forbidden. In the only other case granting recovery under similar circumstances, the damage issue was further complicated by the fact that the action was brought in a federal court which possesses no divorce or alimony jurisdiction. Schoonover v. Schoonover, 172 F. 2d 526 (C.A. 10th, 1949). As alimony awards are traditionally peculiar to divorce proceedings, it was possible to argue that the action should be dismissed for lack of jurisdiction, the theory being that an award of damages for fraud in a divorce agreement is merely another way of granting alimony. Rejecting this argument, the court disposed of the damage problem rather easily, as the wife's "loss-of-bargain" could be ascertained from the face of the contract itself.

${ }^{87}$ While a remodeling of the deceit action so as to permit consideration of "equity" factors may also be possible, it is unlikely. A statutory extension of present alimony doctrines under which the wife's measure of support depends on the spouse's total "equities" seems the best solution. As husbands rather than wives usually assume the major portion of property-transferring burdens incident to divorce, however, the rescission remedy ordinarily affords them ample relief.

${ }^{88}$ Support payments under an unincorporated agreement cannot be enforced by contempt proceedings. See Lindey, Separation Agreements 400 (1937). But if the agreement is incorporated and merged into the divorce decree, contempt preceedings are allowed. E.g., Tripp v. Superior Court, $61 \mathrm{Cal}$. App. 64, 214 Pac. 252 (1923). If the order is to make money payments in a marital property division, however, most courts hold that enforcement by contempt violates constitutional immunities from imprisonment for debt. Edmunson v. Edmunson, 222 N.C. 181, 22 S.E. 2d 576 (1942). The only states holding to the contrary are Colorado and California. Campbell v. Goodbar, 110 Colo. 403, 134 P. 2d 1060 (1943); Miller v. Superior Court, 9 Cal. 2d 733, 72 P. 2d 868 (1937), noted in 26 Calif. L. Rev. 707 (1938). Orders to transfer specific property in a marital property division, however, are in a different constitutional category. See Butler v. Butler, 82 Kan. 130, 107 Pac. 540 (1910).

${ }^{89}$ E.g. Campbell v. Campbell, 328 Ill. App. 322, 65 N.E. 2d 484 (1946); Kraunz v. Kraunz, 293 N.Y. 152, 56 N.E. 2d 90 (1944); Warrington v. Warrington, 160 Ore. 77, 83 P. 2d 479 
or down in accordance with the parties' changed circumstances, ${ }^{90}$ although the original decree is, of course, otherwise final and unalterable with the exception of the fraud, duress and mistake qualifications discussed previously. Nor is the court's power abridged by the existence of a provision in the incorporated agreement that the original payments are not to be altered. ${ }^{91}$ While the indicated results are usually reached solely in terms of the contract's merger into the decree, ${ }^{92}$ alternative grounds, viz., that the spouses cannot by contract divest the divorce court of jurisdiction, ${ }^{93}$ and that the only purpose incorporation could have is to make modification possible, ${ }^{94}$ are also occasionally offered. The counterargument that incorporation was requested only to allay suspicions of the agreement's illegality has been rejected. ${ }^{95}$

As distinct from provisions dealing with alimony, a divorce agreement's property settlement provisions, once adopted in the decree, are inviolable. ${ }^{96}$ Perhaps more litigation has been concerned with the distinction between property and support provisions than with any other phase in the entire divorce agreement area. The most troublesome cases seem to have arisen where it is provided that the wife's alimony payments are to be met out of a large stipulated sum, the residue of which is to be returned to the husband or his estate in the event of the wife's decease or upon her remarriage. ${ }^{97}$ For fear of rendering property settlements inequitable, even alimony modification has been denied where an agreement's alimony and property clauses are closely interdependent..$^{98} \mathrm{~A}$ small minority of courts have also refused modification of alimony in any case where the required payments are to continue after the husband's decease on the theory that the court would have been without jurisdiction to adopt such a provision

(1938). The rule in Ohio, however, seems uncertain. Compare Nash v. Nash, 77 Ohio App. 155, 65 N.E. 2d 728 (1945), with Holloway v. Holloway, 130 Ohio St. 214, 198 N.E. 579 (1935). Of course, if a court has no power to modify an alimony decree, it has no power to modify a decree based on the parties' agreement. See Estes v. Estes, 194 Ga. 95, 14 S.E. 2d 680 (1941).

${ }^{90}$ See authorities cited noted 89 supra. In Illinois, however, the courts have held that regardless of the husband's subsequent improved circumstances, he is only obligated to support the wife in accordance with her station in life at the date of divorce. See Arnold v. Arnold, 332 Ill. App. 586, 76 N.E. 2d 335 (1947) (containing an exhaustive treatment of the cases). In all states, however, the divorce decree is res judicata as to conditions existing at the time of its rendition. E.g., San Fillipo v. San Fillipo, 340 Ill. App. 353, 92 N.E. 2d 201 (1950).

${ }^{91}$ Such provisions are void as being in conflict with the divorce court's mandatory continuing jurisdiction. E.g., Ward v. Ward, 48 R.I. 60, 135 Atl. 241 (1926).

${ }^{22}$ See authorities cited note 89 supra.

${ }^{93}$ See, e.g., Gillespie v. Gillespie, 242 P. 2 d 837 (Ariz., 1952).

94 Reynolds v. Reynolds, 53 R.I. 326, 166 Atl. 686 (1933).

25 Ibid.

${ }^{26}$ E.g., Kohl v. Kohl, 330 Ill. App. 284, 71 N.E. 2d 358 (1947); Hall v. Hall, 105 Colo. 227, . 97 P. 2 d 415 (1939); Erwin v. Erwin, 179 Ark. 192, 14 S.W. 2d 1100 (1929).

${ }^{97}$ For an exhaustive discussion of the problems involved, see Lump Sum Settlement in Lieu of Alimony and Effect of Remarriage Thereon, 45 III. L. Rev. 803 (1951); California Divorce Agreements: Alimony or Property Settlement?, 2 Stanford L. Rev. 731 (1950); Alimony and Property Settlement Provisions Distinguished in Illinois, 44 Ill. L. Rev. 382 (1944).

${ }^{98}$ Poor v. Poor, 237 Mo. App. 744, 167 S.W. $2 d 471$ (1942). And see Int'l Trust Co. v. Liebhardt, 111 Colo. 208, 139 P. 2d 264 (1943). 
without the parties' consent. ${ }^{99}$ In jurisdictions so holding, the loss of permanence and stability of payments, which constitutes the chief disadvantage of incorporation, can easily be averted.

Although most courts have held that judicial power to revise alimony payments is not abridged by the spouses' agreement, the ultimate impact of court modification may sometimes be affected by contract. Where the divorce court has decreed no alimony, it will not subsequently modify the decree and require support payments, whether or not the agreement of the parties is referred to in the decree. ${ }^{100}$ The spouses are left solely to their contract. When the divorce decree is either silent as to alimony or makes express provision against it, the agreement not having merged in the decree, statutes permitting modification for changed conditions have almost uniformly been held inapplicable. ${ }^{101}$ For example, in Kelly v. Kelly, ${ }^{102}$ the Illinois Court, under a statute authorizing the divorce court to "make such alterations in the allowance of alimony . . . as shall appear reasonable and proper," held that an allowance was first necessary in order that an alteration could be made. In contrast, divorce court power to destroy inconsistent, non-merged contract provisions, in the exercise of its admitted authority to revise alimony payments, is not clear. In several states, this problem has not been squarely presented due to the manner in which alimony modification has been dealt with. Whenever alimony revision is sought, such courts have found either that the contract has merged in the decree or that merger has not operated and that the spouses must rely entirely on their contract. ${ }^{103}$ In these jurisdictions, it seems probable that the terms of the decree would prevail if an alimony award inconsistent with the contract was decreed. ${ }^{104}$ In other jurisdictions, the law is clear that a nonmerged agreement may

${ }^{99}$ E.g., Dickey v. Dickey, 154 Md. 675, 141 Atl. 387 (1928). Contra: Marks v. Marks, 265 Mich. 221, 251 N.W. 394 (1933); Armstrong v. Armstrong, 132 Cal. App. 6C9, 23 P. 2d 50 (1933). The courts are divided on the ability of the spouses to expand the jurisdiction of the divorce court by agreement. Compare Wilson v. Wilson, 140 Me. 240, 36 A. 2d 774 (1944), with Conway v. Conway, $130 \mathrm{Kan} .848,288$ Pac. 566 (1930).

100 E.g., Allen v. Allen, 196 Okla. 36, 162 P. 2d 193 (1945); McWilliams v. McWilliams, 110 Colo. 173, 132 P. 2d 966 (1942). Cf. also, Staub v. Staub, 170 Md. 202, 183 Atl. 605, (1936), noted in 50 Harv. L. Rev. 526 (1937); Doeksen v. Doeksen, 202 Iowa 489, 210 N.W. 545 (1926).

${ }^{101}$ The cases are collected in Annotation, 83 A.L.R. 1248, 1250 (1933).

102317 IIl. 104, 147 N.E. 659 (1925), noted in 10 Minn. L. Rev. 254 (1926).

103 E.g., Gillespie v. Gillespie, 242 P. 2 d 837 (Ariz., 1952); Allen v. Allen, 196 Okla. 36, 162 P. $2 d 193$ (1945); McWilliams v. McWilliams, 110 Colo. 173, 132 P. 2 d 966 (1942); Reynolds v. Reynolds, 53 R.I. 326, 166 Atl. 686 (1933); Moore v. Crutchfield, 136 Va. 20, 116 S.E. 482 (1923).

104 This is clearly the result in those jurisdictions where alimony may be awarded inconsistent with the contract in the initial divorce proceedings. See, e.g., Edwards v. Edwards, 113 Colo. 390, 157 P. 2 d 616 (1945). Consult Part I supra, especially note 37 and accompanying text. The emphasis of these courts on the doctrine that the agreement is not binding on the divorce court indicates that provisions of the divorce agreement inconsistent with the divorce decree will be superseded. This argument would apply to the situation where the inconsistency arose from post-divorce modification of the alimony payments as well as to cases where the agreement and the original decree set differing support levels. 
retain its vitality despite the fact that a different amount of alimony has been decreed by the divorce court. ${ }^{105}$ In the latter group of states, breach of contract actions may be maintained for the difference between alimony and contract payments. ${ }^{106}$ Such actions have been permitted only rarely, however, and the unfairness of allowing the wife to obtain new, higher payments enforceable by contempt proceedings while still able to render ineffectual, by an action on the contract, any lowering of payments decreed by the divorce court has occasioned much adverse comment. ${ }^{107}$ In order to avert such injustice, these courts have tended to find that a merger has taken place whenever an agreement is referred to in the divorce decree..$^{108}$

The judicial reception afforded attempts to modify nonmerged agreements because of changed circumstances is in striking contrast to the courts' willingness to modify alimony awards based on divorce contracts. It is axiomatic that changed circumstances rendering the terms of a divorce agreement inequitable do not constitute a defense to the wife's action for breach of contract. ${ }^{109} \mathrm{Al}-$ though a few courts have stated that impossibility of performance will in a proper case bar the wife's action, ${ }^{110}$ no case actually so holding has been uncovered, and the suggestion seems inconsistent with elementary principles of contract law. ${ }^{111}$ The courts have also refused to rewrite the parties' agreement in the light of changed conditions, or to allow hardship as a defense pro tanto. ${ }^{112} \mathrm{An}$ illustrative case is Schillander v. Schillander, ${ }^{113}$ in which the spouses, prior to divorce, entered an agreement providing for $\$ 3 \cup 0$ monthly payments to the wife. The divorce decree was in all respects final and made no reference to the spouses' agreement. In the wife's acticn for arrearages due under the contract, the husband's subsequent remarriage and greatly diminished income were regarded as immaterial. In response to the husband's argument that the parties could not by contract divest the divorce court of jurisdiction, the court replied that the doctrine relied upon was applicable only where an agreement was sought to be interposed as a bar to the awarding of alimony incident to a di-

105 E.g., Holahan v. Holahan, 191 Misc. 47, 79 N.Y.S. $2 d 786$ (S. Ct., 1947), aff'd without opinion, 274 App. Div. 486, 81 N.Y.S. 2d 923 (1948), aff'd without opinion, 298 N.Y. 798, 83 N.E. 2d 696 (1949); Roberts v. Roberts, 83 Cal. App. 345, 256 Pac. 826 (1927). Cf. also, Int'l Trust Co. v. Liebhardt, 111 Colo. 208, 139 P. 2d 264 (1943).

${ }^{106}$ See authorities cited note 105 supra.

107 See Separation Agreements: Actions Thereon, 37 Cornell L.Q. 84 (1951); Paradoxical Separation Agreement, 21 Rocky Mt. L. Rev. 434 (1949); Note, 19 So. Calif. L. Rev. 70 (1945). See also, Rogers, Marriage and Divorce, 39 Mich. L. Rev. 120, 125-27 (1940).

${ }^{108}$ E.g., Murray v. Murray, 278 App. Div. 183, 104 N.Y.S. 2d 55 (1951), noted in 26 St. John's L. Rev. 164 (1951); Hough v. Hough, 26 Cal. 2d 605, 160 P. 2d 15 (1945).

109 E.g., Brown v. Farkas, 195 Ga. 653, 25 S.E. $2 d 411$ (1943); Stark v. Stark, 185 Okla. 348, 91 P. 2d 1064 (1939); North v. North, 339 Mo. 1226, 100 S.W. 2d 582 (1936).

110 See Bier v. Bier, 116 Colo. 89, 178 P. 2d 674 (1945); Stark v. Stark, 185 Okla. 348, 91 P. 2d 1064 (1939).

il Consult Rest., Contracts $\$ 45 \%$, Comment b (1933).

112 See authorities cited notes 109 and 110 supra.

113307 Mass. 96, 29 N.E. 2d 686 (1940). 
vorce. The court conveniently overlooked a line of authority to the effect that agreements entered after the spouses' divorce purporting to adjust or abrogate the wife's future alimony payments do not subsequently interfere with the court's power to enforce the wife's original award. 114 If the spouses' agreement is to be flouted in any case, the doctrine that a divorce court's jurisdiction cannot be abrogated by contract would seem as plausible in the Schillander-type situation as in any other.

Frustration of purpose doctrine has also proved unavailing in post-divorce attempts to secure modification of an agreement's terms because of changed circumstances. Typical is the New Jersey court's rejection, in Moller v. Moller, ${ }^{115}$ of the husband's argument that the maintenance of his contract-date income level formed a basic assumption of the parties' agreement. Even where rescission

114 Cases in which the courts have disregarded agreements made after the entry of a divorce decree providing for alimony in which payments have been modified, rest almost entirely on the doctrine that the divorce court's jurisdiction cannot be privately bargained away. Parmly v. Parmly, 215 N.J. Eq. 545, 5 A. 2 d 789 (1939); Walter v. Walter, 189 Ill. App. 345 (1914); cf. Casilear v. Casilear, 168 Va. 46, 190 S.E. 315 (1937). Occasionally, however, an effort is made to reconcile the result reached in terms of ordinary contract principles. Thus, in Cahill v. Cahill, 316 Ill. App. 324, 334-35, 45 N.E. 2d 69, 74 (1942), where the husband would have been entitled to a reduction of alimony payments because of his son's coming of age two years after the agreement in question was entered, the court held that the wife's acceptance of an amount less than specified in the decree in return for the husband's promise not to seek further reductions and for other benefits was no bar to the court's power to modify at the husband's behest after the son had come of age. The court remarked that the wife "knew that her minor son would become of age in a little more than two years thereafter and that in all likelihood defendant would (then) be allowed a reduction. . . . There was really no consideration on her part ... since she made no concession ... that (the husband) ... was not entitled to as a matter of equity." And cf. Apfelbaum v. Apfelbaum, 11 N.J. Eq. 529, 162 Atl. 543 (1932). Of course, if the agreement is actually without consideration, it will be disregarded. See Johns v. McNabb, 247 S.W. 2d 640 (Mo., 1952).

Perhaps the Hoops' family litigation in New York best illustrates the type of situation involved. In 1934 the wife was awarded an absolute divorce and $\$ 35$ per week alimony. The husband fell into arrears in 1939, and the wife moved to have him committed for contempt. A question arising as to the husband's financial ability, the ex-spouses entered a contract by which the wife received $\$ 7500$ "in full satisfaction for all alimony ... past and future." The final divorce decree was modified to reflect this. With money borrowed from his brother, the husband's $\$ 7500$ payment was duly made. In 1941 , the $\$ 7500$ having since been squandered, the wife brought an equity action to have the agreement set aside, seeking to take advantage of her ex-husband's recently acquired inheritance. Relief was granted by the Appellate Division on the ground that the wife could not, even after divorce, receive a lump sum payment in full settlement of all support claims. Hoops v. Hoops, 266 App. Div. 512, 42 N.Y.S. 2d 635 (1943). This ruling was reversed by the Court of Appeals as failing to recognize that the husband's support duties had been abrogated by the 1934 divorce. The equity action was improper in view of an express finding of no fraud or overreaching of any kind, and that the wife fully understood the purport of the 1939 contract. The proceedings were remanded, however, on the ground that the divorce court's power to modify alimony payments could not be affected even with the divorce court's consent. Hoops v. Hoops, 292 N.Y. 428,55 N.E. 2d 488 (1944). Eventually, the wife was successful in securing a weekly award of $\$ 25$. Hoops v. Hoops, 269 App. Div, 968, 58 N.Y.S. 2d 151 (1945), reargument denied, 269 App. Div. 980, 59 N.Y.S. 2d 294 (1945). Accord: O'Hara v. O'Hara, 137 N.J. Eq. 369, 44 A. 2d 169 (1945). Compare Heflin v. Heflin, 177 Misc. 290,30 N.Y.S. $2 d 412$ (S. Ct., 1941), aff'd without opinion, 263 App. Div. 856, 32 N.Y.S. 2d 1012 (1942).

115121 N.J. Eq. 175, 188 Atl. 505 (1936). See also, North v. North, 339 Mo. 1226, 100 S.W. 2d 582 (1936). 
rather than modification is the remedy sought, the essentially equitable frustration doctrine has seldom been extended to encompass mere financial hardship. ${ }^{116}$ In the rescission area, the chief exceptions have been commercial and real estate contracts where performance was to take place over a long period of time."1r With the possible exception of certain equity cases which have compelled indirect contract modification as a condition to specific performance, 118 no instance of modification because of personal financial hardship has been found. Established rules of risk assumption and the fact that the divorce agreement's distinctive characteristic as compared with direct alimony relief has been the stability and permanence it affords, probably foreclose an extension of frustration doctrine in this area. Although the courts have in various ways recognized and protected against marked changes in the general price level, assumption of risk rather than frustration rules will probably govern here also. ${ }^{119}$ It would seem, however, that a different rule might apply if in a general economic trend the purchasing power of payments fixed by agreement becomes generally and palpably insufficient.

Judicial reluctance to modify directly a divorce agreement's terms because of changed circumstances has thus far been fairly consistent. The doctrine that the spouses' agreement is not binding upon the courts in divorce proceedings has not been extended to permit general revision of nonincorporated agreements. The rule that divorce agreements may not be modified appears to have been receded from in only the two narrowly-defined areas mentioned previously. Where an agreement is referred to in the spouses' divorce decree, many courts have shown great agility in finding that a merger has occurred. ${ }^{120}$ Cases disregarding agreements executed after the entry of an alimony decree form the second exception. ${ }^{21}$ These qualifications aside, the "equitable" notion that a spouse failing to invoke the divorce court's incorporating powers is suffering consequences of his own making has prevailed.

\section{IV}

The diversity in divorce laws and the resultant frequency with which spouses obtain divorces in states other than those in which they live and own property add conflict of laws problems to a large percentage of divorce agreement cases. If a defrauded spouse has secured a decree granting periodic payments based on a divorce agreement, relief for fraud will be afforded in the exercise of the decreerendering state's continuing jurisdiction. ${ }^{122}$ Once obtained, the in personam jurisdiction necessary to any grant of alimony is sufficient if notice of the

${ }^{116}$ For an exhaustive analysis, consult Dawson and Cooper, The Effect of Inflation on Private Contracts: United States 1861-1879, 33 Mich. L. Rev, 852, 860 et seq. (1935).

${ }^{117}$ Ibid., at 893 et seq. See also, Metropolitan Water Board v. Dick, Keer \& Co., [1918] A.C. 119.

${ }^{118}$ E.g., Willard v. Tayloe, 8 Wall. (U.S.) 557 (1869); Behr v. Hurwitz, 90 N.J. Eq. 110, 105 Atl. 486 (1918); Watters v. Ryan, 31 S.D. 536, 141 N.W. 359 (1913).

119 Dawson and Cooper, op. cit. supra note 116, at 886 and authorities there cited.

${ }^{220}$ See notes 103 and 108 supra and accompanying text.

121 See note 114 supra.

122 See note 63 supra and accompanying text. 
modification action is properly given. ${ }^{123}$ The enforcement of final lump sum settlements shown to have been fraudulently procured will be denied in accordance with the ordinary rules governing equitable relief from judgments obtained by fraud ${ }^{124}$ in any state where in personam jurisdiction can be obtained or where the fraudulently obtained judgment is sought to be enforced. ${ }^{125}$ Damage actions for fraud in the procurement of foreign judgments have also been permitted, although no case has been found dealing with divorce agreements. ${ }^{126}$ Such actions are regarded as being in the nature of ordinary actions in equity for relief against fraud. ${ }^{127}$

Where the contract alone has been relied upon, the conflict of laws setting is more diffcult. This is clearly illustrated by the few cases in which tort relief against fraud has been attempted in a forum other than that in which the spouses' divorce had been obtained. In United States National Bank of Denver v. Barlges, ${ }^{128}$ for example, the spouses entered an agreement by which the husband paid to the wife $\$ 325,000$ in lieu "of all claims for alimony and any further share of ... property." The agreement was negotiated after the wife had brought an action for divorce in Kansas. The husband entered an appearance; but later, relying on the terms of the agreement, he withdrew. The final decree provided that "[T] he property settlement . . . is . . a approved . . . and the settlement of mutual rights is fair ... and ... the court makes no order for payment of any alimony." Years later, the wife brought action in Colorado alleging that her husband had concealed the true value of certain securities in the statement of his property holdings. After several years of litigation, the court ultimately ap-

${ }^{123}$ Rest., Judgments $\S 5$, Comment $f$ (1942). A failure to give notice even by publication is a denial of due process. Griffin v. Griffin, 327 U.S. 220 (1946). Notice problems of all sorts might possibly be avoided by the insertion of an appropriate clause in the spouses' divorce agreement. Such a clause might be given effect as a consent to the exercise of continuing personal jurisdiction. Cf. Wilson v. Wilson, 140 Me. 240, 36 A. 2d 774 (1944).

${ }^{124}$ See note 66 supra and accompanying text.

${ }^{125}$ The constitutional status of a foreign judgment against which relief is sought on the ground of its fraudulent procurement is not altogether clear. There are three basic views. The first is that the foreign judgment is valid and entitled to full faith and credit in all states and that relief, if any, must be sought in the forum where the judgment was secured. Christmas v. Russell, 5 Wall. (U.S.) 290 (1896). The Supreme Court has never authoritatively rejected this view, and a few early cases have followed it. More recent full faith and credit developments, however, cf., New York ex rel. Halvey v. Halvey, 330 U.S. 610, 614-15 (1947), support the second and prevailing opinion which holds that the fraudulently procured judgment is entitled to no greater respect in another state than it has where rendered. Levin v. Gladstein, 142 N.C. 482 , 55 S.E. 371 (1906). And cf., Titus v. Wallick, 306 U.S. 282 (1939) (indicating that if the judgment is valid where rendered, even though there was fraud, it must be treated as valid elsewhere). A third view is set forth in Wyman v. Newhouse, $93 \mathrm{~F} .2 \mathrm{~d} 313$ (C.A. 2d, 1937) (holding that a Florida judgment was not entitled to full faith and credit in a federal tribunal regardless of its status in Florida).

${ }^{126}$ E.g., Griffith v. Bank of New York, 147 F. 2d 899 (C.A. 2d, 1945). Consult 31 Am. Jur. Judgments $\$ \S 615,654$ (1940).

${ }^{127}$ See authorities cited note 126 supra.

128120 Colo. 317, 210 P. 2d 600 (1949), cert. denied, 338 U.S. 955 (1949), aff'd, 122 Colo. 546,224 P. $2 d 658$ (1950). 
proved an award of damages for almost two million dollars. ${ }^{129}$ The defense relied principally upon the doctrine of full faith and credit, buttressing its argument by the terms of a Kansas statute which precluded an attack on any judgment for fraud more than two years after it had once become final. According to the Colorado court, the difficulty was that the agreement had not, under the applicable law, become merged in the decree so that the doctrines of res judicata and full faith and credit were not applicable. ${ }^{130}$

Conceding that the agreement had not become merged in the decree, the assertion that a judgment of damages for fraud in respect of a final, court-approved divorce agreement is substantially different from an actual award of alimony seems startling. However, the case is clearly not a violation of the full faith and credit clause since the Kansas court's "approval" of the settlement could not be enforced by contempt proceedings ${ }^{131}$ and since the wife's right to alimony had never been decided in the Kansas divorce action.

The recent New York case of Weintraub v. Weintran $b^{132}$ has reached a result contrary to that of Bartges. The plaintiff wife brought action in New York seeking to recover from her former husband $\$ 100,000$ based on his alleged fraud in inducing her to enter a divorce agreement during the pendency of an ex parte divorce action which she successfully prosecuted in New Jersey. The contract was not mentioned in the New Jersey decree. Plaintiff expressly disclaimed any desire to modify or set aside the contract. The Court of Appeals held that the action could not be maintained. Alimony was not a property right in the sense that a wife could be defrauded of her right to it; the statutory actions of New York were exclusive; and the court had no jurisdiction to make any alimony or support award except as incident to a divorce or judicial separation action.

The full impact of this holding must be measured in the context of New York alimony and support law. Like most other states, New York has no statute permitting post-divorce alimony suits, regardless of where the divorce was obtained; and the Court of Appeals has held that the power to make such awards can only be derived from statute. ${ }^{133}$ Following the majority rule, the New York courts have refused to modify the terms of any foreign support of alimony decree; ${ }^{134}$ to do so it is held, would be to deny the foreign decree full faith and credit. Only domestic decrees may be modified. ${ }^{135}$ It is clear, then, that the

129 U.S. Nat'l Bank of Denver v. Bartges, 122 Colo. 546, 224 P. $2 \mathrm{~d} 658$ (1950).

${ }^{130}$ See Magnolia Petroleum Co. v. Hunt, 320 U.S. 430, 439 (1943). "[T]he clear purpose of the full faith and credit clause (is) to establish ... that a cause of action merged in a judgment in one state is likewise merged in every other."

131 See note 88 supra. 132302 N.Y. 104, 96 N.E. $2 d 724$ (1951).

${ }^{133}$ See Weintraub v. Weintraub, 302 N.Y. 104, 96 N.E. 2d 724 (1951) (containing an excellent discussion of the authorities).

134 E.g., Schacht v. Schacht, 295 N.Y. 439, 68 N.E. 2d 433 (1946); Calderon v. Calderon, 275 App. Div. 251, 88 N.Y.S. 2d 886 (1949).

${ }^{135}$ See Separation Agreements: Actions Thereon, 37 Cornell L.Q. 84 et seq. (1951). If the view that a wife's right to alimony is property, implicit in the Bartges case, is to be accepted, an argument can be made that it is unconstitutional to deny post-divorce relief for fraud in the case of foreign decrees whenever relief against fraud would be afforded in the case of domes- 
defrauded Mrs. Weintraub's only remedy is to petition the New Jersey Court for a modification of its decree. This is, of course, no remedy at all; the husband, by staying out of New Jersey, could successfully evade service. The New Jersey tribunal would be unable to make a binding award.

As indicated previously, a defrauded wife in Mrs. Weintraub's position need not be left without remedy. ${ }^{136}$ Subject to strict equitable limitations, the right to apply for post-divorce alimony should be provided and joined with an action for rescission. Constitutionally, the fact that a foreign decree is involved would in most instances be immaterial. The Supreme Court's decision in Estin v. Estin ${ }^{137}$ appears to remove all doubt as to the legality of domiciliary alimony awards in the case of a foreign ex parte decree. Where the husband has secured the foreign decree, many states have long entertained such actions. ${ }^{38}$ Independent postdivorce relief has also occasionally been afforded in related situations. ${ }^{139}$ The traditional barriers to more generalized relief, i.e., that the marital status on which the power to award alimony depends no longer exists ${ }^{140}$ and that the prior decree is res judicata ${ }^{141}$ are of domestic creation. Even if both parties appeared in the foreign divorce action, full faith and credit would seem to permit a subsequent domestic alimony award provided the wife's right to alimony had not actually been adjudicated in the foreign proceedings. In fact, where the wife has been denied alimony, full faith and credit would not protect any foreign decree

tic decrees. Such discrimination seems unreasonable. A similar argument was employed by the Supreme Court in Estin v. Estin, 334 U.S. 541 (1948), where it was suggested that a deprivation of the wife's property interest in a prior support order by a foreign divorce decree, where the wife had not been personally served, was violative of due process. The traditional answer to this view is that the right to support is contingent upon the continued existence of the marital relation. But even if the concept that divorce is unitary should be accepted by individual states, to permit the concept to alter the basic fact of discrimination itself would seem an unusual triumph of form over constitutional substance.

${ }^{136}$ See note 76 supra and accompanying text.

${ }^{137} 334$ U.S. 541 (1948). And see Kreiger v. Kreiger, 334 U.S. 555 (1948). In each of these cases, the Court held that full faith and credit did not require the termination of a prior domestic support order in deference to a foreign ex parte divorce decree. "The result . . . is to make divorce divisible - to give effect to the ... (foreign) decree insofar as it affects marital status and to make it ineffective on the issue of alimony." Estin v. Estin, 334 U.S. 541, 549 (1948). Although both of these cases involved a prior support order, their rationale, the economic interest of the domiciliary state, seems equally applicable to the case of post-divorce alimony.

${ }^{138}$ E.g., Davis v. Davis, 70 Colo. 37, 197 Pac. 241 (1921); Searles v. Searles, 140 Minn. 385, 168 N.W. 133 (1918). A majority of states permit relief in this situation. See Award of Alimony Subsequent to a Decree of Divorce, 34 Ky. L.J. 149 (1946); Alimony: Power of Court to Award Alimony Subsequent to Divorce, 34 Calif. L. Rev. 193 (1946).

${ }^{139}$ Thus a few states, contrary to the majority rule, have entertained independent postdivorce alimony actions where the wife has obtained a foreign divorce on constructive service and the husband later comes into the decree-rendering jurisdiction. E.g., Stephenson v. Stephenson, 54 Ohio App. 239, 6 N.E. 2d 1005 (1936). Cf. also Karcher v. Karcher, 204 Ill. App. 210 (1917). For additional situations in which relief has sometimes been afforded, see Comments cited note 138 supra.

${ }_{160}$ E.g., Staub v. Staub, $170 \mathrm{Md} .202,212,183$ Atl. 605, 610 (1936); Hall v. Hall, $141 \mathrm{Ga.}$ 361, 80 S.E. 992 (1914); Howell v. Howell, 104 Cal. 45, 37 Pac. 770 (1894).

14 E.g., McCoy v. McCoy, 191 Iowa 473, 183 N.W. 377 (1921); Cameron v. Cameron, 31 S.D. 335,140 N.W. 700 (1913). 
later subject to modification in the state in which it was rendered..$^{142}$ The obstacle here, of course, is that most states presently regard such adjudications as conclusive. As a defrauded wife's right to alimony will seldom be at issue when an unincorporated divorce agreement is employed, however, constitutional doctrine will practically never constitute a barrier to the suggested form of relief. Should any jurisdiction recede from the present unanimous unwillingness to afford protection against changed conditions, the conflict of law considerations applicable to relief from fraud would presumably govern in this area also. ${ }^{143}$

\section{$\mathrm{V}$}

In summary, the choice between incorporation and reliance on the contract alone depends largely upon the objectives sought. Apart from exceptional cases, the decision to incorporate need not be influenced by the statements of a majority of courts that the spouses' contract is not binding in divorce proceedings. Invalidity may result, however, where the bargain struck is likely to appear prejudicial to the wife at the time of the divorce. Aside from tax advantages, the primary incidents of incorporation are found in contempt sanctions and in the availability of judicial alimony revision upon a material change of circumstances. Determining whether or not a merger has occurred is often a complex process. As incorporation by reference does not usually effectuate a merger, care must be taken that the agreement is expressly adopted in the divorce decree. Absolute certainty as to the divorce agreement's status is especially important in states where breach of contract actions may be maintained for the difference between the alimony and contractual levels of support. If the original settlement is later attacked for fraud, incorporation will prove of advantage in any case

142 " $[\mathrm{A}]$ judgment has no constitutional claim to a more conclusive or final effect in the State of the forum than it has in theState where rendered. ... And if the amount payable under a decree-as in the case of a judgment for alimony-is discretionary with the court which rendered it, full faith and credit does not protect the judgment." New York ex rel. Halvey v. Halvey, 330 U.S. 610, 614-15 (1947). See Foster, The Enforcement of Foreign Alimony Decrees, 4 So. Car. L.Q. 541 (1952); Conflict of Laws: Use of Florida Equitable Remedies to Enforce Foreign Alimony Decree, 4 Fla. L. Rev. 243 (1951); Effect of Limited Decrees on Later Suit for Absolute Divorce, 31 Ore. L. Rev. 62, 69 (1951); 1947-48 Term of the Supreme Court: Interstate Status of Divorce, 48 Col. L. Rev. 1083 (1948).

${ }^{143}$ As far as agreements merged in divorce decrees are concerned, the enforcement and modification of foreign decrees has until very recently been confined to a bare constitutional minimum. As only final judgments are constitutionally entitled to recognition, relief has been denied whenever the payment of alimony is so discretionary with the issuing court that a vested right to receive it does not exist. See Lynde v. Lynde, 181 U.S. 183 (1901). In going beyond the minimum dictates of full faith and credit, several courts have enforced non-final foreign decrees on the explicit basis of "comity." E.g., Cousineau v. Cousineau, 155 Ore. 184, 63 P. 2d 897 (1937). A few courts have held that full faith and credit does not permit otherwise. Fanchier v. Gammill, 148 Miss. 723, 114 So. 813 (1927). Even temporary foreign alimony awards are coming to be enforced. See Extra-State Enforcement of Temporary Alimony, 47 Col. L. Rev. 279 (1947). The outer limit of extra-state recognition of foreign decrees has been reached in the few jurisdictions indicating a willingness to afford relief against changed circumstances where a foreign decree is subject to modification in the state where rendered. It would seem that any troublesome problems of nonfinality could be adequately dealt with by providing for immediate amendment of the domiciliary order to meet any changes in the original decree. See Rule v. Rule, 313 Ill. App. 108, 39 N.E. 2d 379 (1942). And see Comments cited note 143 supra. 
where an agreement providing for periodic payments has been employed. In the case of the lump-sum agreement, incorporation will occasionally work against relief, as some courts refuse to modify their decrees for fraud in the nature of property concealment. A Bartges-type action being impossible, the contract having merged in the decree, the defrauded wife must in these jurisdictions go remediless. Rather than expand the scope of the tort action, however, flexible equitable remedies such as rescission coupled with the right to post-divorce alimony or a direct modification of the divorce decree appear preferable.

The chief significance of reliance on the divorce agreement alone is the protection afforded against support payment revision because of changed circumstances. Judicial disregard of the spouses' agreement has not often been extended beyond cases where the wife violates her promise to submit the agreement to the court or where a contract is entered after divorce purporting to adjust the wife's alimony rights. Both groups of cases are inconsistent with the respect afforded contracts attacked because of changed conditions, and both disregard the plainly expressed policy of the Married Women's Property Acts. The simple divorce, as compared with the incorporated agreement, is of much less utility to defrauded wives. Conflict of laws problems highlight this disadvantage. Rescission of the divorce agreement being worthless, a tort action of the Bartges variety is the only remedy available. In the case of fraudulent wives, however, rescission will ordinarily afford defrauded husbands ample relief.

While the respective incidents of simple as compared with incorporated divorce agreements are easily described, the choice between them often proves illusory. Decisions actually casting aside divorce agreements have been few. But the uncertainty raised by frequent judicial assertions that divorce agreements may be disregarded on grounds which are baseless when judged by ordinary contract principles have in many cases made incorporation necessary. Federal tax policies have contributed to the same end. To the degree that it exists, judicial and legislative hostility to divorce agreements ought to be reconsidered. The ease with which a wife may currently entitle herself to alimony is phenomenal. The "guilty husband" rationale for the making of such payments is in many cases pure myth. The potentialities of enforceable divorce agreements as ameliorative devices for the worst of our alimony abuses are great. That husbands do not often contest their wives' divorce actions is well known; and when they do, it is almost always because of inordinate alimony or property demands. The atmosphere of divorce courts is not conducive to enlightened and equitable settlements, not only because they are in practical effect largely ex parte, but because the true facts often cannot be brought to light. Unsatisfied marriage partners should be able to adjust their "equities" in private with the positive assurance that the bargain finally agreed upon will later be dealt with as any other contract. Currently, the presence of uncertainty and the tax discrimination attendant upon simple divorce agreements constitute two of the most important reasons for deciding to incorporate. Divested of these two "benefits," the advantages of incorporation hardly seem sufficient to justify a whittling away of the spouses' freedom to settle their own divorce problems. 